\title{
Thermal Stable Perovskite Solar Cells Improved by ZnO/Graphene Oxide as Electron Transfer Layers
}

\author{
JIANG Wen-Long ${ }^{1,2}$, ZHOU Wei ${ }^{1}$, YING Ji-Fei ${ }^{1}$, YANG Tie-Ying ${ }^{2}$, GAO Yan-Min ${ }^{1}$ \\ (1. The college of Materials Science and Engineering, Jiangsu University of Science and Technology, Zhenjiang 212003, China; \\ 2. Shanghai Institute of Applied Physics, Chinese Academy of Sciencs, Shanghai 201204, China)
}

\begin{abstract}
ZnO}$ /graphene oxide (GO) nano-particles (NPs) layer was prepared using a facile solution process and employed as an electron conductor to improve the thermal stability of perovskite solar cells. Structural changes during the degradation process in high temperature environment were characterized via in situ grazing incidence X-ray diffraction. The optical properties and surface morphologies of the films were characterized. It was observed that smooth and compact structure of $\mathrm{ZnO} / \mathrm{GO}$ layer works as a protection layer to prevent decomposition of perovskite film which is converted into $\mathrm{PbI}_{2}$ during the annealing process reaction. The perovskite film grown on $\mathrm{ZnO} / \mathrm{GO}$ layer exhibited enhanced crystallization, high surface coverage ratio as well as preferred in-plane orientation of the (110) plane.
\end{abstract}

Key words: GIXRD; $\mathrm{ZnO} / \mathrm{GO}$; perovskite; ETL (electron transfer layers)

Efficient solar cells comprising earth-abundant and nontoxic metal-oxide absorbers are very attractive due to the sustainable material usage and potential for cost-effective manufacturing $^{[1]}$. In particular, the discovery of hybrid perovskite as a light absorbing component has been a breakthrough. Since the first reports by Miyasaka, et $a l^{[2]}$, solar-cell-devices based on hybrid perovskites of $\mathrm{CH}_{3} \mathrm{NH}_{3} \mathrm{PbX}_{3}(\mathrm{X}=\mathrm{I}, \mathrm{Br}, \mathrm{Cl})$ type have been improved in power conversion efficiencies (PCEs) from 3.8\% to $20.8 \%$ in only a few years ${ }^{[3-4]}$.

To fabricate perovskite solar cells, different types of electron transfer layers (ETLs) and hole transfer layers (HTLs) have been employed. Regarding the ETL materials, more stable metal oxides, such as titanium dioxide $\left(\mathrm{TiO}_{2}\right)$, zinc oxide $(\mathrm{ZnO})$, and tin oxide $\left(\mathrm{SnO}_{2}\right)$ have been developed for perovskite solar cells ${ }^{[5]}$. Among these metal oxides, $\mathrm{TiO}_{2}$-nanoparticles (NPs) have been commonly used as the ETL to provide an efficient charge collection. To prepare a $\mathrm{TiO}_{2}$ mesoporous layer, a sintering process with high temperature $\left(\approx 500^{\circ} \mathrm{C}\right)$ is required ${ }^{[6]}$. This temperature is too high for fabrication. What's more, the lack of thermal stability of perovskite solar cells is hindering the progress of this technology towards adoption in the consumer market. $\mathrm{ZnO}$ NPs are, therefore, a promising candidate to replace $\mathrm{TiO}_{2}$ as the ETL layer in perovskite solar cells.
However, only a few works have reported perovskite solar cells based on ZnO NPs. The devices on ZnO NPs show a maximum PCE of close to $15.7 \%{ }^{[4]}$, which is lower than those on $\mathrm{TiO}_{2} \mathrm{NPs}$. In addition, a few works have demonstrated the instability of perovskite materials on top of $\mathrm{ZnO}$ NPs after annealing at a relative high temperature, especially using a one-step process ${ }^{[7]}$. What's more, other researchers have demonstrated that the annealing of the perovskite at lower temperature results in poor device performance ${ }^{[8]}$. Recently, a monolayer of graphene with a honeycomb lattice has attracted considerable attention for use in photovoltaic applications due to the fact that they work as a fast electron funnel. Wang, et $a l^{[9]}$ demonstrated that the hybrid nanostructure of graphene and $\mathrm{TiO}_{2} \mathrm{NPs}$ can improve performance of a perovskite solar cell up to $15.6 \%$.

In this work, we synthesized smooth $\mathrm{ZnO} / \mathrm{GO}$ film and employ it as an ETL in a perovskite solar cell to explore whether $\mathrm{CH}_{3} \mathrm{NH}_{3} \mathrm{PbI}_{3}$ perovskite material after being deposited on top of the layer could be higher stability after annealing process at $100^{\circ} \mathrm{C}$ due to the formation of the hybrid structure( $\mathrm{ZnO} / \mathrm{GO})$.

\section{Experimental}

\subsection{Materials and devices fabrication}

Methylammonium iodide (MAI) was synthesized

Received date: 2016-04-01; Modified date: 2016-05-10

Foundation item: National Natural Science Foundation of China (11405253, U1332205); Youth Innovation Promotion Association CAS and the Research Program of Science and Technology Commission of Shanghai Municipality (14DZ2261200)

Biography: JIANG Wen-Long(1989-), male, candidate of Master degree. E-mail: jiangwenlong123@126.com

Corresponding author: GAO Yan-Min, professor. E-mail: 957661528@qq.com

YANG Tie-Ying, professor. E-mail: yangtieying@sinap.ac.cn 
according to the literature ${ }^{[10]}$.GO was obtained from a modified Hummer's method withflake expandable graphite used as the original material according to a previously reported protocol ${ }^{[11]}$. To prepare the perovskite precursor solution, MAI (99\%, Materwin Techology) and lead iodide $\left(\mathrm{PbI}_{2}, 99.999 \%\right.$, Alfa) powder were mixed in anhydrous N,N-dimethylformamide (DMF, 99.9\%, Aldrich) with a molar ratio of 3:1. The perovskite precursor solution was stirred at $60^{\circ} \mathrm{C}$ for $6 \mathrm{~h}$ and filtered through PTFE filters $(0.45 \mu \mathrm{m})$ prior to use. The glass substrate coated with patterned indium tin oxide (ITO) with a sheet resistance of $10 \Omega / \square$ was cleaned with a detergent, ultrasonicated in acetone and ethanol, and then blow dried with nitrogen. Subsequently, the substrates were treated with ultraviolet ozone plasma for $15 \mathrm{~min}$. $50 \mathrm{~nm}$ thick layer of $\mathrm{ZnO} / \mathrm{GO}$ was deposited on the ITO substrates by the cathodic electrophoretic deposition (EPD) technique that can be found described elsewhere ${ }^{[12-13]}$. $40 \mathrm{wt} \% \mathrm{CH}_{3} \mathrm{NH}_{3} \mathrm{PbI}_{3}$ precursor solution was spin-coated at $3500 \mathrm{r} / \mathrm{min}$ for $60 \mathrm{~s}$. After lying in a petri dish at room temperature for $15 \mathrm{~min}$, the perovskite films were annealed on a hot plate at $100^{\circ} \mathrm{C}$ for $30 \mathrm{~min}$, allowing the color of the films to turn to black. Subsequently, The spin coating formulation was prepared by dissolving $72.3 \mathrm{mg} \mathrm{2,2}, 7,7^{\prime}$-Tetrakis(N,N-p-dimethoxyphenylamino)-9,9'-spirobifluorene(spiro-MeOTAD), purchased from Alfa, $30 \mu \mathrm{L}$ 4-tert-butylpyri-dine and $20 \mathrm{~mL}$ of a stock solution of $520 \mathrm{mg} / \mathrm{mL}$ lithium bis (trifluoromethylsulphonyl) imide in acetonitrile in $1 \mathrm{~mL}$ chlorobenzene. Finally, 90-nm-thick gold electrodes were deposited on top of the devices by evaporation at $10^{-4} \mathrm{mbar}$.

\subsection{Characterization}

The microstructure of each sample was characterized by $\mathrm{X}$-ray diffraction (XRD) and in situ grazing incidence X-ray diffraction (GIXRD) at beamline BL14B1 beamline of the Shanghai Synchrotron Radiation Facility (SSRF) using $\mathrm{X}$-rays at a wavelength of $0.124 \mathrm{~nm}$. Two-dimensional GIXRD(2D-GIXRD) images were acquired with a MarCCD, mounted vertically, at a distance of $364 \mathrm{~mm}$ from the sample, with a grazing angle of incidence of $2^{\circ}$ and an exposure time of $20 \mathrm{~s}$. The 2D GIXRD patterns were analyzed using the FIT2D software and displayed in scattering vector q coordinates, where $q=4 \pi \sin \theta / \lambda, \theta$ is half of the diffraction angle, and $\lambda$ is the X-ray wavelength. Transmittance spectra were recorded via a UV-Vis spectrophotometer (UV3010). The surface morphologies of the samples were observed by atomic force microscopy (AFM) (Nanoscope IIIa). The surface morphology of films was observed by scanning electron microscope (SEM, LEO1530). Device characteristics and PCE were measured in a glovebox under a Newport 94023A solar simulator equipped with a $300 \mathrm{~W}$ Xenon lamp, and an air
mass(AM) $1.5 \mathrm{G}$ filter was used to generate a simulated AM $1.5 \mathrm{G}$ solar spectrum irradiation source.

\section{Results and discussion}

\subsection{Surface structure of $\mathrm{ZnO} / \mathrm{GO}$ NPs}

To study the surface of the $\mathrm{ZnO}$ film, X-ray diffraction (XRD) is employed. Fig. 1(a) and 1(b) show XRD pattern of the $\mathrm{GO}$ and $\mathrm{ZnO} / \mathrm{GO}$ films, where the diffraction peaks of the $\mathrm{ZnO} / \mathrm{GO}$ film are related to the crystalline $\mathrm{ZnO}$ (JCPDS 36-1451). In Fig. 1(a), peaks of the GO layer were found at $2 \theta=25.81^{\circ}, 43.51^{\circ}$ and peaks at $25.81^{\circ}$, $43.51^{\circ}$ exsisted in Fig. 1(b) support the successful formation of the hybrid structure.

\subsection{Properties of $\mathrm{ZnO} / \mathrm{GO}$ NPs}

To probe the effect of $\mathrm{ZnO} / \mathrm{GO}$ film as an ETL, its surface morphology and optical properties were studied. Ultraviolet-visible (UV-Vis) spectroscopy (Fig. 2(a)) of $\mathrm{ZnO} / \mathrm{GO}$ film as compared to $\mathrm{ZnO}$ film shows an auxiliary enhanced absorption edge to longer wavelengths (a redshift of $\approx 18 \mathrm{~nm}$ ) because of the size effect. As shown in Fig. 2(b), $\mathrm{ZnO} / \mathrm{GO} \mathrm{NPs}(0.85 \mathrm{~nm})$ becomes larger than $\mathrm{ZnO}(0.26 \mathrm{~nm})$ due to the hybrid structure. Fig. 2(c) depicts the top-view SEM image of this layer with a high coverage and uniformity. The surface roughness of the
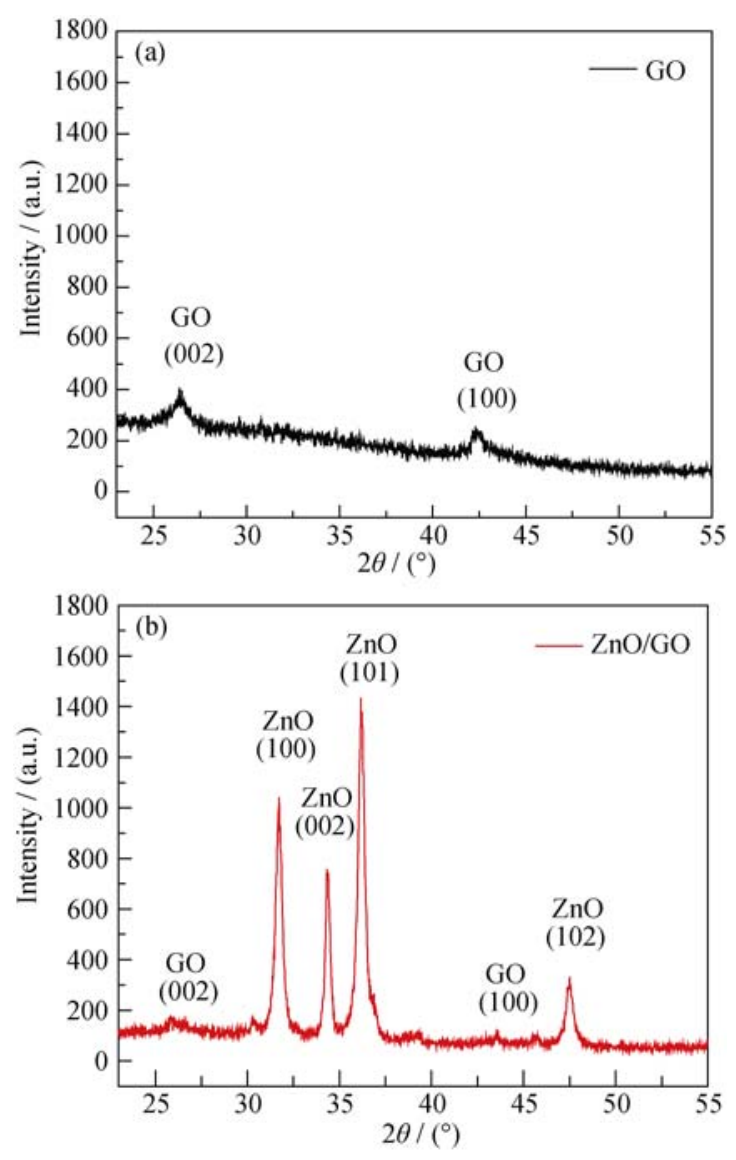

Fig. 1 XRD patterns of $\mathrm{GO}$ and $\mathrm{ZnO} / \mathrm{GO}$ films 

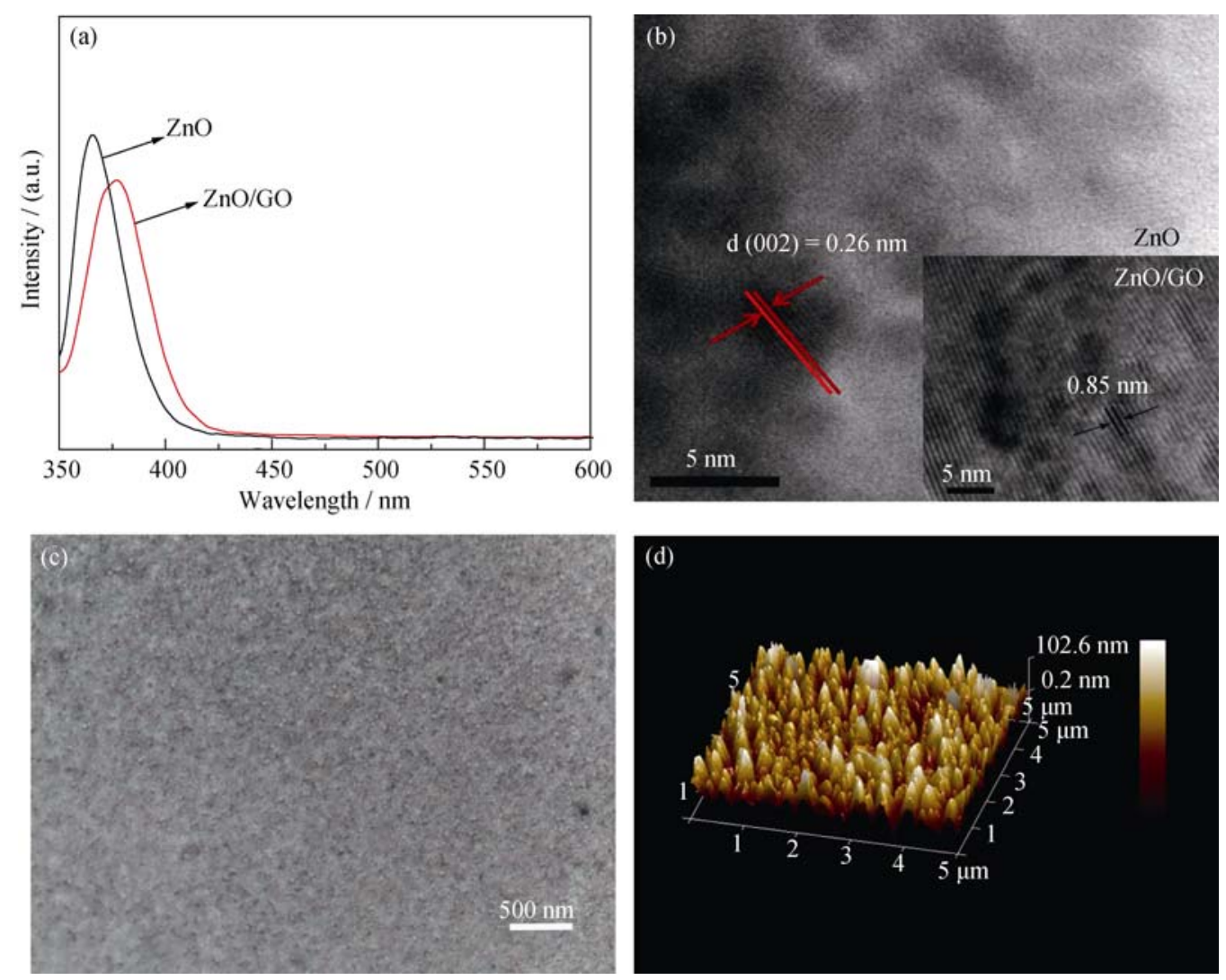

Fig. 2 (a) UV-Vis absorption and (b) TEM images of $\mathrm{ZnO} / \mathrm{GO}$ films and $\mathrm{ZnO}$ film. (c) Top-view SEM image and (d) AFM image of $\mathrm{ZnO} / \mathrm{GO}$ films

films were further monitored using high-resolution atomic force microscopy (AFM), as shown in Fig. 2(d). The size of the AFM images is $5 \mu \mathrm{m} \times 5 \mu \mathrm{m}$. The root mean square (RMS) roughnesses of $\mathrm{CH}_{3} \mathrm{NH}_{3} \mathrm{PbI}_{3}$ film deposited on $\mathrm{ZnO} / \mathrm{GO}$ layer was approximately $28.9 \mathrm{~nm}$, indicating that it is suitable for the replacement of $\mathrm{ZnO}$ layer as the ETL.

\subsection{GIXRD studies}

Snapshots of the in situ GIXRD experiments at various points in time are shown in Fig. 3. All of the GIXRD patterns exhibited a relatively strong scattering background from the amorphous glass substrate in the range of $q=10-25 \mathrm{~nm}^{-1}$, where $q$ is the scattering vector $(q=4 \pi \sin (\theta) / \lambda)$. After calibration, key features of the perovskite diffraction pattern could be observed at $q \approx 10.04,19.74$ and $22.21 \mathrm{~nm}^{-1}$. These are consistent with reflection from the (110), (220) and (310) lattice planes, respectively ${ }^{[14]}$.

Fig. 3(a) is the diffraction pattern of the $\mathrm{CH}_{3} \mathrm{NH}_{3} \mathrm{PbI}_{3}$ film deposited on $\mathrm{ZnO} / \mathrm{GO}$ after heating at $100^{\circ} \mathrm{C}$ in air for $2 \mathrm{~min}$, which reveals that the film is polycrystalline with preferred in-plane orientation of the (110) plane. The strong and sharp (110) peaks imply that the films possess good crystallization and large crystal size. When the film was heated to $100^{\circ} \mathrm{C}$ for $15 \mathrm{~min}$ (Fig. 3(b)), a new feature at $q \approx 9 \mathrm{~nm}^{-1}$ appeared, which is consistent with reflection from the (001) planes of $\mathrm{PbI}_{2}$ (PDF\#07-0235), but the ring is not so clear, indicating that just a little amout of $\mathrm{CH}_{3} \mathrm{NH}_{3} \mathrm{PbI}_{3}$ decomposed after $20 \mathrm{~min}$. Yang ${ }^{[7]}$ studied the $\mathrm{CH}_{3} \mathrm{NH}_{3} \mathrm{PbI}_{3}$ film deposited on $\mathrm{ZnO}$, suggesting that after $13 \mathrm{~min}$ of heating at $100^{\circ} \mathrm{C}$, the perovskite decomposes into $\mathrm{PbI}_{2}$ in a single step. Herein, it can be concluded perovskite structure on the $\mathrm{ZnO} / \mathrm{GO}$ showed a higher stability than it on $\mathrm{ZnO}$. According to Fig. 3(c), it can be found that, after $30 \mathrm{~min}$, the perovskite (110) feature still exsist clearly. These data show that after $15 \mathrm{~min}$ of heating at $100^{\circ} \mathrm{C}$, only small part of $\mathrm{CH}_{3} \mathrm{NH}_{3} \mathrm{PbI}_{3}$ decomposes into $\mathrm{PbI}_{2}$, consistent with the result we indicated above.

\subsection{Performance of solar cell}

Table 1 summarizes the photovoltaic parameters of devices measured under AM $1.5 \mathrm{G}$ solar illumination at $100 \mathrm{~mW} / \mathrm{cm}^{2}$. As presented from the data, the common $\mathrm{TiO}_{2}$-based device results in an efficiency of $10.24 \%$. Regarding to the devices employing $\mathrm{ZnO}$ as an ETL, efficiencie of $9.08 \%$ was obtained. When an $\mathrm{ZnO} / \mathrm{GO}$ layer is introduced into the solar cell, a PCE of $9.31 \%$ isobtained, corresponding to an open circuitvoltage $\left(V_{\mathrm{oc}}\right)$ of $1.00 \mathrm{~V}$, a short circuit current density $\left(J_{\mathrm{sc}}\right)$ of $18.30 \mathrm{~mA} / \mathrm{cm}^{2}$, and a fill factor $(F F)$ of 0.51 . Therefore, $\mathrm{ZnO} / \mathrm{GO} \mathrm{NPs}$ layer is suitable for use in perovskite solar cells.

In order to study the role of $\mathrm{ZnO} / \mathrm{GO} \mathrm{NPs}$ in the device 

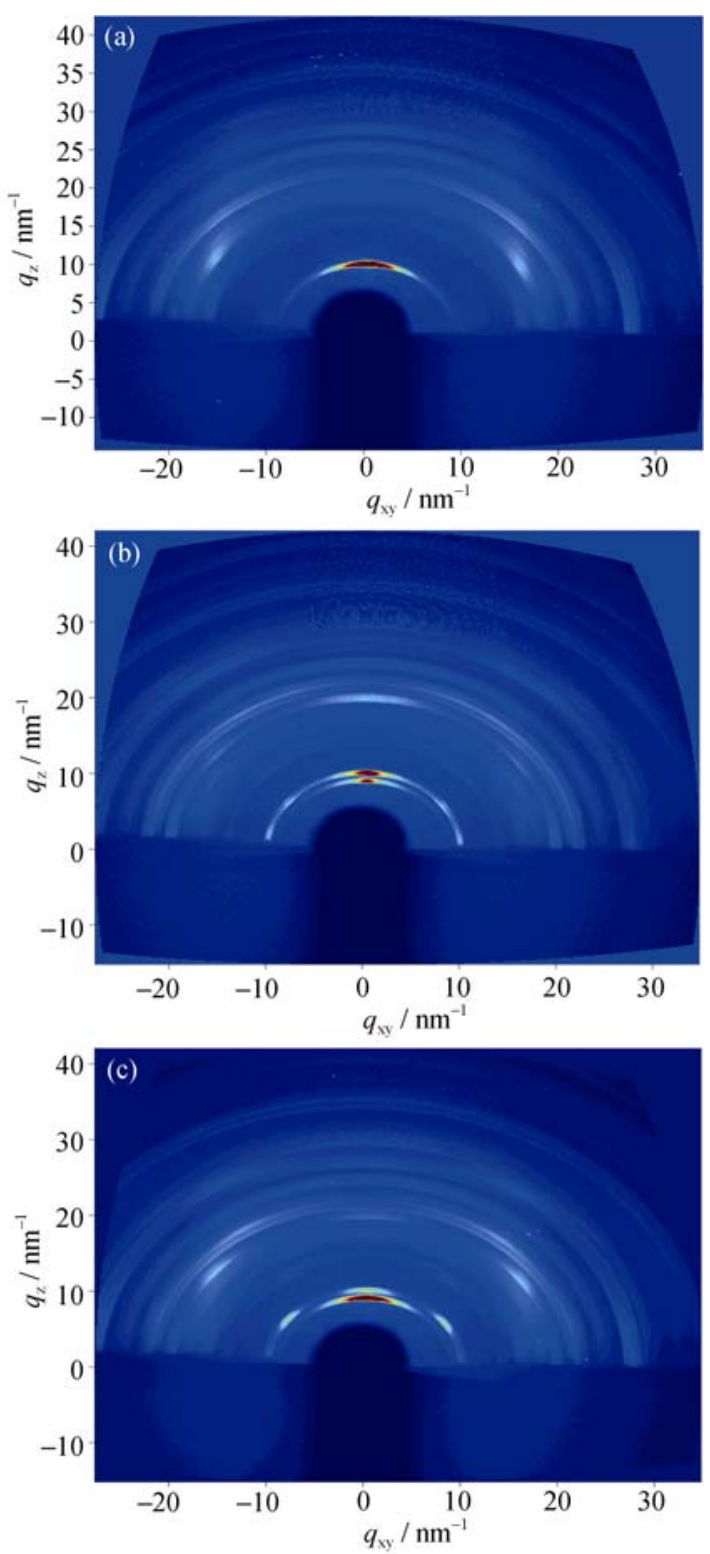

Fig. 3 2D GIXRD patterns of ITO/( $\mathrm{ZnO} / \mathrm{GO}) / \mathrm{CH}_{3} \mathrm{NH}_{3} \mathrm{PbI}_{3}$ film after heating at $100^{\circ} \mathrm{C}$ in air for $2 \min (\mathrm{a}), 15 \mathrm{~min}(\mathrm{~b})$, and $30 \min (\mathrm{c})$

Table 1 Photovoltaic parameters of solar cells with different ETL

\begin{tabular}{ccccc}
\hline $\mathrm{ETL}$ & $J_{\mathrm{SC}}\left(\mathrm{mA} \cdot \mathrm{cm}^{-2}\right)$ & $V_{\text {oc }} / \mathrm{V}$ & $F F$ & $\eta / \%$ \\
\hline $\mathrm{TiO}_{2}$ & 17.06 & 0.79 & 0.75 & 10.24 \\
$\mathrm{ZnO}$ & 13.71 & 0.92 & 0.72 & 9.08 \\
$\mathrm{ZnO} / \mathrm{GO}$ & 18.30 & 1.00 & 0.51 & 9.31 \\
\hline
\end{tabular}

structure, we have designed a stability test using two samples based on $\mathrm{ZnO}$ NPs and $\mathrm{ZnO} / \mathrm{GO}$ NPs as ETL sealed by UV-epoxy. As demonstrated in Fig. 4, the PCE of the perovskite solar cell on $\mathrm{ZnO} / \mathrm{GO} \mathrm{NPs}$ drops only $\sim 5 \%$ after $15 \mathrm{~d}$, which is much more stable that the $\mathrm{ZnO}$ one ( $\sim 80 \%$ drop). This experiment supports the importance of $\mathrm{GO}$ in order to reduce the reaction between $\mathrm{MAPbI}_{3}$ and $\mathrm{ZnO}$ NPs.

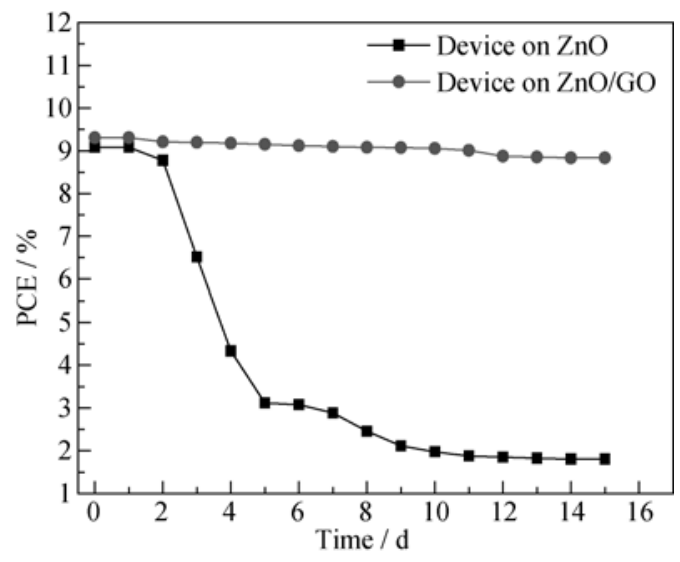

Fig. 4 Stability of the devices based on $\mathrm{ZnO}$ NPs and $\mathrm{ZnO} / \mathrm{GO}$ NPs in an ambient environment after encapsulation using UVepoxy

\section{Conclusion}

In order to tackle the problem of heat-induced degradation, we have successfully demonstrated a smooth and compact structure of $\mathrm{ZnO} / \mathrm{GO}$ NPs according to the XRD result and employ it as an ETL in the perovskite solar cell. Perovskite solar cell with the new hybrid structure has a relative high efficiency of $9.31 \%$. Using this hybrid structure, $\mathrm{MAPbI}_{3}$ perovskite material demonstrates much improved stability through in situ grazing incidence X-ray diffraction even with the annealing process at $100^{\circ} \mathrm{C}$. The high quality of the $\mathrm{ZnO} / \mathrm{GO} \mathrm{NPs}$ and good opto-electrical, surface properties make it a candidate of photoelectric materials for the applications in the future.

Acknowledgement The authors thank the staff of beamline BL14B1 at the Shanghai Synchrotron Radiation Facility.

\section{References:}

[1] KRAMER I J, SARGENT E H. The architecture of colloidal quantum dot solar cells: materials to devices, Chem. Rev., 2013, 114: $863-882$.

[2] KOJIMA A, TESHIMA K, SHIRAI Y, et al. Organometal halide perovskites as visible-light sensitizers for photovoltaic cells. $J$. Am. Chem. Soc., 2009, 131(17): 6050-6051.

[3] BI D, TRESS W, DAR M I, et al. Efficient luminescent solar cells based on tailored mixed-cation perovskites. Sci. Adv., 2016, 2(1): $1150-1170$.

[4] LIU D Y, KELLY T L. Perovskite solar cells with a planar heterojunction structure prepared using room-temperature solution processing techniques. Nature Photon, 2014, 8(2): 133-138. 
[5] ZHU Z, ZHENG X, BAI Y, et al. Mesoporous $\mathrm{SnO}_{2}$ single crystals as an effective electron collector for perovskite solar cells. Phys. Chem. Chem. Phys., 2015, 17(28): 18265-18268.

[6] CHENG Y, YANG Q D, XIAO J, et al. Decomposition of organometal halide perovskite films on zinc oxide nanoparticles. ACS Appl. Mater. Interfaces, 2015, 7(36): 19986-19993.

[7] YANG J, SIEMPELKAMP B D, MOSCONI E, et al. Origin of the thermal instability in $\mathrm{CH}_{3} \mathrm{NH}_{3} \mathrm{PbI}_{3}$ thin films deposited on $\mathrm{ZnO}$. Chem. Mat., 2015, 27(12): 4229-4236.

[8] TAVAKOLI M M, TAVAKOLI R, NOURBAJHS Z, et al. High efficiency and stable perovskite solar cell using $\mathrm{ZnO} / \mathrm{rGO}$ QDs as an electron transfer layer. Adv. Mater. Interfaces, 2016, 1500790: 1-10.

[9] WANG J T W, BALL J M, BAREA E M, et al. Low-temperature processed electron collection layers of graphene/ $/ \mathrm{TiO}_{2}$ nanocomposites in thin film perovskite solar cells. Nano Letters, 2013, 14(2): 724-730.
[10] LEE M M, TEUSCHE J, MIYASAKA T, et al. Efficient hybrid solar cells based on meso-superstructured organometal halide perovskites. Science, 2012, 338(6107): 643-647.

[11] LIU Z, ROBINSON J T, SUN X, et al. PEGylated nanographene oxide for delivery of water-insoluble cancer drugs. Chem. Soc., 2008, 130(33): 10876-10877.

[12] TAVAKOLI M M, AASHURI H, SIMCHI A, et al. Hybrid zinc oxide/graphene electrodes for depleted heterojunction colloidal quantum-dot solar cells. Phys. Chem. Chem. Phys., 2015, 17(37): 24412-24419.

[13] SON D I, KWON B W, PARK D H, et al. Emissive ZnO-graphene quantum dots for white-light-emitting diodes. Nature Nanotech, 2012, 7(7): 465-471.

[14] FROST J M, BUTLER K T, BRIVIO F, et al. Atomistic origins of high-performance in hybrid halide perovskite solar cells. Nano Letters. 2014, 14: 2584-2590.

\title{
ZnO/GO 纳米材料基热稳定钙钛矿太阳能电池
}

\author{
姜文龙 ${ }^{1,2}$, 周 伟 ${ }^{1}$, 应纪飞 ${ }^{1}$, 杨铁莹 ${ }^{2}$, 高延敏 ${ }^{1}$
}

(1. 江苏科技大学 材料科学与工程学院, 镇江 212003; 2. 中国科学院 上海应用物理研究所, 上海 201204)

摘 要: 为了使钙针矿太阳能电池在高温退火后能够保持稳定, 本研究通过电化学方法制备出氧化锌/氧化石墨烯 纳米粒子, 并将其运用到钻钠矿太阳能电池中作为电子传输层使用。通过原位掠入射 X 射线衍射 (GIXRD)、X 射线 衍射(XRD)、扫描电子显微镜(SEM)和紫外-可见吸收光谱(UV-Vis)等方法对沉积在氧化锌和氧化锌/氧化石墨烯纳 米材料上面的甲胺铅碘的结构、形貌以及电池性能变化进行分析测试。结果表明: 氧化锌/氧化石墨烯对于甲胺铅 碘有保护作用, 沉积在氧化锌/氧化石墨烯上面的甲胺铅碘薄膜稳定性更高，电池性能更加稳定，为将来大面积应 用提供了一定的指导。

关 键 词: 掠入射 X 射线衍射; 氧化锌氧化石墨烯; 钻钛矿; 电子传输层

中图分类号: TQ174 文献标识码: A 